\title{
FORMAL AND INFORMAL SUPPORT SYSTEMS FOR SINGLE WOMEN AND SINGLE MOTHERS IN MALAYSIA
}

\author{
Noraida Endut \\ Women's Development Research Centre (KANITA) \\ Universiti Sains Malaysia, \\ Penang, Malaysia \\ Azman Azwan Azmawati \\ Women's Development Research Centre (KANITA)/ School of Communication \\ Universiti Sains Malaysia, \\ Penang, Malaysia \\ Intan Hashimah Mohd Hashim \\ Women's Development Research Centre (KANITA)/ School of Social Sciences \\ Universiti Sains Malaysia, \\ Penang, Malaysia
}

\begin{abstract}
The aim of this paper is to explore how formal and informal supports were being experienced by single women and single mothers in Malaysia. Closely examining formal and informal support systems reported by single mothers and single women in Malaysia, participants generally reported good and were mainly satisfied with their informal support system. Informal support system comprised of mostly family members and friends. However, formal support system was still lacking and both single women and single mothers were more likely to report an "unfriendly" formal support system. Findings provide important policy and theoretical implications suggesting the need for a more gender-sensitive governmental policy and practice.
\end{abstract}

Keywords: informal support system, formal support system, single women, single mothers, Malaysia

\section{INTRODUCTION}

Malaysia is seeing a rapid change to its demographic scenario. The population is getting older with the life expectancy at birth of men reaching 72.6 and while that of women reaching 77.2 years old (Statistics Department, 2013). The mean age at first marriage for Malaysian women has also increased to 28.6 years. As more women received higher education and enter the job market, Malaysia is also seeing an increasing number of women becoming single mothers or remain unmarried.

Although single women and single mothers may be two different categories of experiences for women, many challenges they face may be similar or comparable. Given the normative view that a married family is a "normal' family, it is very likely that family policies and programmes tend to veer towards the "normal" and ignore those who are single (either unmarried, separated, divorced or widowed, with or 
without children) but who are expected to take up various key roles as members of families. Anecdotes and articles gleaned from women's magazines have highlighted families and societal expectations of working single women which tend to expect more willingness to shoulder responsibilities and to assume greater roles. Increasingly, women become single or primary heads of households as a result of divorce, being abandoned by their spouses or of being widowed.

Giving new insights and perspectives on what is it like to be single women and single mothers in the real-world context in Malaysia and forms of supports they received or managed to obtain is the purpose of this paper. The paper will also explore the women's assessment of the adequacy of the various forms of support available to them. This is so that recommendations could be made towards policy and advocacy considerations in giving appropriate assistance to single women and single mothers, who should be enjoying the the rights and access to development on the same basis as any other citizens.

\section{WOMEN, MARRIAGE AND SINGLEHOOD IN MALAYSIA}

In Southeast Asia, with the exception of Singapore, between 1970 and 2000, women are generally married by the age of 25 (Jones, 2010). Nevertheless, the trend over the stated years show a general pattern of marriage delay in these nations. In Malaysia, women are also choosing to enter marriage at a higher age now than before. The average at first marriage in 2010 show a 0.6 year's increase from that of 2000. In 2000 the average age at first marriage is 25.1 and in 2010 it rises to 25.7 (Department of Statistics, Malaysia, 2010a). In Malaysia, between 1970 and 2000, the mean age at first marriage show increases for women. In 1970, the mean age was 22.1 and the corresponding mean ages for 1980, 1991 and 2000 are 23.5, 24.7 and 25.1 respectively (Zarina Mahari et al, 2011). In 2010, 13.6 percent of women aged 25 and above in Malaysia are never married (Department of Statistics, Malaysia, 2010b). The corresponding percentage for 2000 is 10.4 (Department of Statistics, Malaysia, 2000). The proportion of women who are still single (i.e. never married) at the age of 35-39 in 2000 in Indonesia, the Philippines, Thailand and Myanmar are 3.5, 9.5, 11.5 and 18.6 percent respectively (Jones, 2010). The corresponding percentage for Malaysia is 7.8 and this percentage increases for Malaysia to 10.8 in 2010.

In Malaysia, increased singlehood is argued to be the "compositional" effect of increased women's achievement in education (Jones and Gubhaju, 2009). It is said that education and career considerations had expanded women's horizons, giving them opportunities which competed with the marriage. Issues like migration, urbanisation and modernisation had also resulted in women having more autonomy in making decisions, including in those relating to marriage (The Star, March 11, 2010). Despite these postulations, however, single women, while increasing in number, remains an 
understudied group in Malaysia. Within the academic setting, a debate on singlehood in Malaysia is not a popular topic and hence, discourses on such issue are difficult to come by and not much substantial survey research can be found. Relevant studies are mainly confined to issues on population research. The lived realities of single or never married women are important aspects to be studied in the context of possible discrimination they may face as a result of deep socio-cultural structures around them. These structures may inform policies and practices on issues related to provisions of formal support for citizens and if the situation of women in this category is not studied, they may be left out from the enjoyment rights and benefits of development.

Single mothers is another category of female citizens who may be associated with specific demands and challenges in the Malaysian society. Conventionally, a single mother in Malaysia is defined as a woman whose husband is deceased and who bears the burden of taking care of children of the marriages upon the deaths, or a woman who is divorced and given the custody of her children (Rohaty and Muhammad Rais, 1999; M. Bakri Musa, 2002). However, a woman deserted by her husband and who, as a result, is taking care of her children without her husband's support; a woman in the process of divorce whose husband is not contributing towards the financial and other forms of support for their children; a woman who is the sole earner and caregiver in her family as a result of her husband falling ill and a woman who is taking care of other people's children without the support of her husband may also be considered a single mother (M. Bakri Musa, 2002). This is because the structure and dynamics of the familial relationship that she is living in is similar to those of a legally divorced or widowed woman.

Single mothers in Malaysia, especially those aged 40 years and above often have very minimal savings and often face great difficulties entering or reentering the workforce (UNDP, 2012). In 2012, incidents of poverty amongst female-headed households in Malaysia is 2.1 percent compared to 1.6 percent for households headed by men (Department of Statistics, Malaysia, 2012). The corresponding incidents for hardcore poor is 0.3 for female-headed and 0.2 for male headed households (ibid.). There is no conclusive recorded number of single women in Malaysia. However, in 2010, 808,787 women from the age of 15 were recorded as widowed, divorced or separated (Department of Statistics, Malaysia (2010b). This number was equivalent to 8.3 percent of all women in Malaysia. The majority of women who were widowed were in the age group 60-64 years while the majority of women who were divorced or separated were in the age group of 40-44 years. A 2009 study found that women aged 40 and above formed 80 percent of low income female-headed households (Dasimah, Puziah and Muna, 2009). The study also found that 23 percent of these women became single as a result of divorce while 72.1 percent are widowed. The study had focused on respondents with monthly income below RM1200 
and but further found that 92 percent of the respondents lived with monthly income below RM1000 with the majority in this group earning less than RM500 a month.

Looking from the perspective of wellbeing, life as a single mother has been associated with higher level of chronic stress and episodes of depression compared to married mothers (Cairney, Boyle, Offord \& Racine (2003). Stressors for single mothers are primarily financial issues but may also extend to parental issues and issues of social interactions (Olson and Banyard, 1993). Single mothers living in urban areas in Malaysia have been shown to feel highly dissatisfied with supports offered by formal agencies such as the Welfare Department and Religious Departments ((Dasimah, Puziah and Muna, 2009). Issues such as the availability of public amenities are also high on the list of grievance of urban single mothers (ibid.).

\section{METHODOLOGY}

\section{Respondents}

In the study, participants were 200 single women 300 single mothers between the who were purposively sampled throughout Peninsular Malaysia. Respondents were identified via personal contact or using a systematic snowballing technique. In the systematic snowballing technique, advertisements were placed around a public university for recruitment of enumerators. As a result, twenty-six university students were recruited as enumerators and they were requested to identify potential respondents. The criteria for respondents were Malaysian women between the ages of 18 and 66 and these women must have been married before and have become single at the point of the study. A face to face interviewing technique was employed in gathering data from the respondents.

\section{Interview schedule}

The study on which this paper is based is conducted by interviewing respondents using a semistructured schedule consisting of 16 thematic sections. For the purpose of this paper, sections on background information, social networking and formal support structures are analysed. The section on background information establishes respondents' socio-demographic backgrounds including age, ethnicity, religion and socio-economic status. The section on social networking consists of respondents listing of up to ten persons they consider the most important persons in their lives, their accounts of how these persons contribute towards their wellbeing and their assessment of the sense of happiness the relationships with these persons have brought to them. The section on formal support structures require respondents to give open-ended responses to questions about the available of formal or state- 
sponsored supports to them and their assessment of whether these forms of supports treat them, as compare to other citizens, in an equal and non-discriminary manner.

\section{FINDINGS AND ANALYSES}

\section{Single women and single mothers in Malaysia: a demographic overview}

As mentioned earlier in this paper, little is currently known about the socio-demographics of single women and single mothers in Malaysia. This paper set out to present a picture of recent backgrounds Table 1 is a summary of the ages, ethnicities and religions of the single women and single mothers interviewed.

Single women who were interviewed were between the ages of 27 and 60 years. The mean age for single women was 41.35 (SD 8.86). In addition, 43 percent of the single women were aged between 30-39 years while 44.5 percent were aged between 40-54 years. Based on Malaysian statistics of 2010, for unmarried women aged 25 and above ${ }^{1}, 50.6$ percent are aged 30 years and above. In addition, 42.1 percent of women aged 25 and above who are never married are women in the age group of 30-54 years.

The 300 single mothers who were interviewed were between the ages of 18 and 86 years. The mean age for single mothers was 49.81 (SD 9.19). The single mothers are heavily represented by women in the age group of between 40-59 years, with 41.33 percent being in the age group 45-54 years. It should be noted that according to the statistics of 2010, 41.6 percent of women who were divorced or separated were in the age group of 40-54 years while 32.1 percent of women who were widowed were in the age group of $40-59$ years.

\footnotetext{
${ }^{1}$ The average age at first marriage for women in 2010 is 25.7 years.
} 
SHS Web of Conferences

Table 1: Demographic backgrounds of single women and single mothers

\begin{tabular}{|c|c|c|c|c|c|c|}
\hline & Age & $F(\%)$ & Ethnicity & $F(\%)$ & Religion & $F(\%)$ \\
\hline \multirow[t]{9}{*}{ Single Women } & $25-29$ & $8(4.00)$ & Malay & $143(71.5)$ & Muslim & $146(73)$ \\
\hline & $30-34$ & $51(25.50)$ & Chinese & $24(12)$ & Christian & $10(5)$ \\
\hline & $35-39$ & $35(17.50)$ & Indian & $30(15)$ & Hindu & $29(14.5)$ \\
\hline & $40-44$ & $19(9.50)$ & Other & $3(1.5)$ & Buddhist & $15(7.5)$ \\
\hline & $45-49$ & $41(20.50)$ & & & & \\
\hline & $50-54$ & $29(14.50)$ & & & & \\
\hline & $55-59$ & $12(6.00)$ & & & & \\
\hline & $\geq 60$ & $2(4.00)$ & & & & \\
\hline & Missing & $3(1.50)$ & & & & \\
\hline TOTAL & & $200(100)$ & & $200(100)$ & & $200(100)$ \\
\hline Mean & & 41.35 & & & & \\
\hline SD & & 8.86 & & & & \\
\hline \multirow[t]{11}{*}{ Single Mothers } & $18-24$ & $2(0.67)$ & Malay & & Muslim & \\
\hline & $25-29$ & $7(23.33)$ & Chinese & & Christian & \\
\hline & $30-34$ & $25(8.33)$ & Indian & & Hindu & \\
\hline & $35-39$ & $33(11.00)$ & Other & & Buddhist & \\
\hline & $40-44$ & $40(13.33)$ & Missing & & Other & \\
\hline & $45-49$ & $63(21.00)$ & & & Missing & \\
\hline & $50-54$ & $61(20.33)$ & & & & \\
\hline & $55-59$ & $48(16.00)$ & & & & \\
\hline & $60-64$ & $13(4.33)$ & & & & \\
\hline & $\geq 65$ & $7(23.33)$ & & & & \\
\hline & Missing & $1(0.33)$ & & & & \\
\hline TOTAL & & $300(100)$ & & $300(100)$ & & $300(100)$ \\
\hline Mean & & 49.81 & & & & \\
\hline SD & & 9.19 & & & & \\
\hline
\end{tabular}

Table 2: Socio-economic status of single women and single mothers

Table 3: Reasons for currently being single

\begin{tabular}{|l|r|r|r|r|}
\hline & \multicolumn{3}{|l|}{ Single Women } & \multicolumn{2}{l|}{ Single Mothers } \\
\hline Reason for being single & $\mathrm{F}$ & $\%$ & $\mathrm{~F}$ & $\%$ \\
\hline Have yet to meet a suitable partner & 113 & 56.50 & 9 & 3.00 \\
\hline Divorced & 6 & 3.00 & 74 & 24.7 \\
\hline Death of partner/ spouse & 9 & 4.50 & 166 & 55.3 \\
\hline Personal choice & 22 & 11.00 & 0 & 0.00 \\
\hline Sexually, I don't like men & 6 & 3.00 & 3 & 1.00 \\
\hline Other & 9 & 4.50 & 2 & 0.70 \\
\hline Missing data & 35 & 17.50 & 46 & 15.30 \\
\hline TOTAL & $\mathbf{2 0 0}$ & 100 & 300 & 100 \\
\hline
\end{tabular}




\section{Informal support}

The findings of this study shows that 52 percent of single women and 40 percent of single mothers strongly agree or completely agree that they are satisfied with the relationships they have with their family and their friends. In 78.5 percent of the cases for single women and 88.7 percent of the cases for single mothers, women frequently share their feelings with family or close friends. The majority of single women ( 59.5 percent) and single mothers ( 60 percent) agree that they cope with problems by getting family members or close friends to join them in activities unrelated to the problems.

Single mothers list children as the most important persons in their lives 72.8 percent of them listing either daughters, sons or children generally as the most important persons in their lives. The five most important persons in single mothers' lives based on majority of reports is contained in Table 4.

Table 4: The most important persons in single women's and single mothers' lives

\begin{tabular}{|c|c|c|}
\hline $\begin{array}{c}\text { Order of } \\
\text { importance }\end{array}$ & Single women & Single mothers \\
\hline 1 & Mother & Children \\
\hline 2 & Father & Mother \\
\hline 3 & Siblings & Siblings \\
\hline 4 & Friends & Father \\
\hline 5 & Others & Friends \\
\hline
\end{tabular}

Daughters and mothers are high in single mothers' and single women's lists of important people and this is possibly due to the affinity they feel towards female members of the family. Relatives and friends who are important to them make them feel loved, confident of their abilities and happy. In certain circumstances, these persons help them financially and also assist them in organising their daily lives.

\section{Formal structures}

Single women have mixed feelings about the availability of support from state agencies towards them. They are of the opinions that generally there are no specific programmes for single women as compared to programmes for single mothers. However In certain circumstances, single women feel that they need certain assistance especially in the forms of special considerations for loan eligibility because they sometimes lack willing guarantors for credits. Single women in these circumstances may face social safety net issues in their senior years due to inability to own their accommodation due to inability to secure housing loans. 
Single mothers in this study were able to list a number of programmes by state agencies that had helped single mothers in general. However, there were a few issues with regard to this programmes. Some programmes were not accessible to women who were not active in certain community activities. Single mothers faced problems getting involved in these activities due to issues such as childcare and work hours. Single mothers also face similar issues as single women in getting loans due to the inability to find willing guarantors. Employers were also thought to be more cautious about employing single mothers and this may influence the economic empowerment of single mothers.

\section{CONCLUSION}

Single women and single mothers are groups of women that require specific studies and analyses. Their growing number in Malaysia means that more and more households are being single- and female-headed. While single women and single mothers report fair satisfaction with availability informal support structure in the forms of family members and friends, these support may be inadequate in ensuring that they are able to enjoy development on the same basis as any other citizens. Informal support may increase single women's and single mothers' sense of emotional wellbeing however, in the long run, it may not be able to contribute towards their socio-economic and practical needs such as the getting out of poverty and getting support to day-to-day organisations of lives. Findings of the study on which this paper is based is hoped to establish theoretical implications and inform policy on the need for a more gender-sensitive intervention to groups of women at risk of socio-economic marginalisation.

\section{REFERENCES:}

Dasimah Omar, Puziah Ahmad and Muna Sarimin (2009). "Urban living conditions of low income single mothers in Malaysia”. European Journal of Social Sciences, Volume 9, Number 2 (2009), 193201

Department of Statistics, Malaysia (2012a). Abridged life tables, 2009-2011. Kuala Lumpur: Department of Statistics, Malaysia

Department of Statistics, Malaysia (2012b). Incidence of poverty by sex and ethnic group of head of household, Malaysia, 2012. Kuala Lumpur: Department of Statistics, Malaysia. http://www.statistics.gov.my/portal/ (accessed on 25th March 2014)

Department of Statistics, Malaysia (2010a). Population distribution and basic demographic characteristic report 2010. http://www.statistics.gov.my/portal/ (accessed on 25 th March 2014)

Department of Statistics, Malaysia (2010b). Population aged 15 years and over by marital status, age group, sex, ethnic and state, Malaysia, 2010. Kuala Lumpur: Department of Statistics, Malaysia 
Department of Statistics, Malaysia (2000). Population aged 15 years and over by marital status, age group, sex, ethnic and state, Malaysia, 2000. Kuala Lumpur: Department of Statistics, Malaysia

Jones, Gavin W. (2010). "Changing patterns of marriage in Asia", Asia Research Institute Working Paper Series No. 131

Jones, Gavin W. and Gubhaju, Bina (2009). "Trends in marriage in the low fertility countries of East and Southeast Asia". Asian Population Studies, 5(3), 237-265

M. Bakri Musa (2002). Malaysia in the era of globalisation. Lincoln: Writer's Club Press

Rohaty Mohd Majzud \& Muhammad Rais Abd. Karim (1999). Ibu tunggal menelusuri rintangan hidup dengan keyakinan. Selangor: Pelanduk Publications

Zarinah Mahari, Wan Roslida Othman, Noor Masayu Mhd Khalili, Sabariah Esa and Nadia Miskiman (2011). "Demographic transition in Malaysia: the changing roles of women". Paper presented at the 15th Conference of Commonwealth Statisticians, New Delhi India, 7-10 February, 2011

United Nations Development Program, 2012. "MDG1 and 3 - Towards a National Action Plan to Empower Single Mothers project". http://www.undp.org.my/news_details.php ?nid=66\&title= MDG1\%20and\%203\%20-\%20Towards\%20a\%20National\%20Action\%20Plan\%20to\%20 Empower\%20Single\%20Mothers\%20project (accessed on 20th March 2014) 